\title{
Journalists at the border: An analysis of their work when covering news on immigration
}

\author{
María Ruiz-Aranguren; María-José Cantalapiedra
}

Nota: Este artículo se puede leer en español en:

http://www.elprofesionaldelainformacion.com/contenidos/2020/mar/ruiz-cantalapiedra_es.pdf

How to cite this article:

Ruiz-Aranguren, María; Cantalapiedra, María-José (2020). “Journalists at the border: An analysis of their work when covering news on immigration". El profesional de la información, v. 29, n. 2, e290210.

https://doi.org/10.3145/epi.2020.mar.10

Manuscript received on $5^{\text {th }}$ April 2019 Approved on $19^{\text {th }}$ December 2019
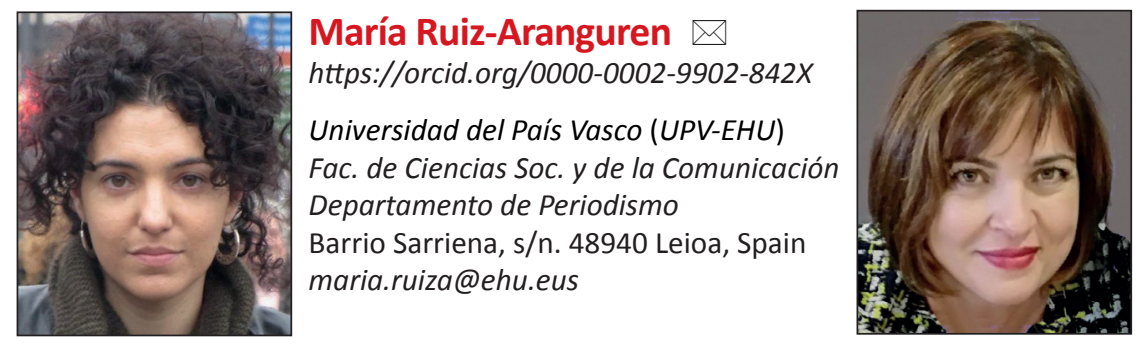

María-José Cantalapiedra https://orcid.org/0000-0003-4961-2326

Universidad del País Vasco (UPV-EHU) Fac. de Ciencias Soc. y de la Comunicación Departamento de Periodismo II Barrio Sarriena, s/n. 48940 Leioa, Spain mariajose.cantalapiedra@ehu.eus

\begin{abstract}
This study analyses the media coverage of immigration in Melilla, the land frontier between Spain and Morocco and one of the access points where immigrants enter the European Union, and the role that journalists and other agents play in spreading news on immigration. By means of a field study we analyse the type of news professionals and media that are present near the border, the logics followed by institutional press offices when providing information, and the particular conditions in which journalism is practiced in a space of juridical exceptionality. Amongst the results obtained we underscore: the predominance of a media market that, while apparently diverse, is highly dependent on institutional advertising; the relevance of figures like activists or freelance journalists in providing differentiated news on immigration; and the difficulties in working that journalists face due to arbitrariness and obscurantism when accessing images and data.
\end{abstract}

\section{Keywords}

News production; Press offices; Institutional advertising; Activists; Activism; News; Freelance; Journalism; Journalists; Media professionals; Censorship; Immigration; Professional practice; Borders; Access to information; Interviews; Spain; Morocco; Melilla.

\section{Introduction}

In recent decades the analytical study of frontier spaces has pivoted around the notion of human rights principally considered from the field of law, whose critical facet denounces the regulation of migrations according to judicial criteria characteristic of neoliberal globalisation. On one side, some scholars question the bodies of regulations of the European Union and its member states (in Spain Organic Law 4/2000) and their dissociation from human rights (Contreras-Hernández, 2016), as the latter are linked to the migrant person's administrative situation. On the other, they analyse the normative standards of supranational institutions like the International Organization for Migration, the World Trade Organization or the European Union itself, which

"are regulating the flows of migrants attending to the needs of the world market" (Barbero-González, 2011).

\section{Acknowledgements}

This work has been possible thanks to the program "Convocatoria de contratación para la especialización de personal investigador en la UPV/EHU”, enjoyed by María Ruiz-Aranguren under the direction of María-José Cantalapiedra. It is also included in the results of the CSO2014-46196-R project, financed by the Spanish Ministry of Economy and Competitiveness, led by María-José Cantalapiedra. 
Since the 1980s there have been two predominant research currents on migrations from the perspective of the communications field.

- On one side, critical discourse analysis (CDA), which focuses on discovering the forms on which the reproduction of social domination is based; in this case, supremacy according to ethnic group, skin colour or place of origin (Alcaraz-Mármol; Soto-Almela, 2016; Bañón-Hernández, 2002; Fajardo-Fernández; Soriano-Miras, 2016; Van-Dijk, 2016).

- On the other, the theory of News Framing, understood as an extension of Agenda-Setting, which has made it possible to reflect on which affairs are covered by the mass media and how these affairs are considered (Allen; Blinder, 2013; McCombs; López-Escobar; Llamas, 2000).

Both currents enable us to obtain a diagnosis of the quality of news on immigration and to observe that, although conclusions have varied amongst countries, the predominant coverage focuses on issues and frames that associate negative values with immigrants (Gemi; Ulasiuk; Triandafyllidou, 2013). In this sense, there is a tendency to develop narratives associating these people, on one side, with a threat to the economy (Caviedes, 2015) and, on the other, with crime or terrorism (Armentia-Vizuete; Marín-Murillo; Caminos-Marcet, 2015; Fuentes-Osorio, 2005; Wagman, 2002).

However, insufficient attention has been paid to the method of working of journalists and the mass media, in spite of the fact that the news on migrations published and broadcast by the mass media cannot be separated from the legislation on immigration questions, which influences both the terminology employed and journalistic approaches (Prieto-Andrés, 2017).

There are some studies, although still very few, that are starting to widen understanding of the complexity in which the media operate. Some scholars have shown that the mass media and journalists are not the main agents in providing news on immigration and that it is the activists who play a primordial role (Agirre; Ruiz-Aranguren; Cantalapiedra, 2015; González-de-Bustamante, 2018). Furthermore, we can find investigations that dissect the relationship of journalists with their sources when reporting on immigration (Bleich; Bloemraad; De-Graauw, 2015) or that examine the use of style manuals and ethical codes (González-Cortés; Sierra-Caballero; Benítez-Eyzaguirre, 2014). The work that comes closest to being a study of journalistic work on the border is the publication Reporting at the Southern borders (Dell'Orto; Birchfield, 2014), which is a compilation of first-hand testimonies of reporters.

At the same time, we can find studies by scholars who are critical of the mass media and define their own mission as being to provide other perspectives. In this sense, Ferrer Gallardo \& Gabrielli observe that

"the rhetoric of emergency, crisis and exceptionality accompanies the way migration is managed, and obscures other fundamental and structural components of the frontier process" (Ferrer-Gallardo; Gabrielli, 2018).

For her part, Liliana Suárez Navaz has brought out a compilation of articles by anthropologists in response to the

"inappropriateness of media coverage and the death of thousands of people at sea" (Suárez-Navaz, 2015).

Following the same line, a group of academics (Last et al., 2017) consulted the official registers of five countries in order to collect data on the number of people who have died attempting to cross frontiers. The existing databases are based on information that has appeared in the media, which indicates that in those areas not reached by journalists there might be silence and obscurantism.

Keeping these antecedents in mind, the goal of the investigation presented here is to understand how journalists and other possible relevant informants on the frontier work when they publish or broadcast news on migrant arrivals. For this purpose, we based our study on the theoretical current that studies news production (Tuchman; Gaye, 1978), a perspective that in recent years is also being revisited by other scholars who consider that many of the biases found in news stories are related to production criteria (Gemi; Ulasiuk; Triandafyllidou, 2013; Hoxha; Hanitzsch, 2017; Ruiz-Aranguren; Cantalapiedra, 2018a; 2018b; Preston, 2008). In that respect, theoreticians have for long been noting the importance of studying professional practice to gain a better understanding of the limits that distinguish the exercise of journalism from other types of practice, in light of the proliferation of other agents that provide news (Carlson; Lewis, 2015). Furthermore, they underline the importance of understanding the conditions in which professionals produce news stories and observe that

"journalists will never again control the flow of information in the way they once did" (Wahl-Jorgensen; Hanitzsch, 2009).

The study of production can similarly advance our understanding of the mobility of information and its impact on audiences at different levels that exceed the local, national and international administrative structures (Archetti, 2015).

The research questions were as follows:

Q1: What type of news professionals operate on the border covering crossings by migrants and what role do they play?

Q2: The border is a space of interest to local, national and international audiences, how do professionals deal with their work in that context?

Q3: Keeping in mind that the border is an exceptional space in politico-legal terms, in what conditions do they practice their profession? 


\section{Methodology}

In this work we used a qualitative methodology based on conducting semi-structured interviews. Additionally, it is based on a methodological model designed on the basis of the work of a doctoral thesis (Ruiz-Aranguren, 2014).

This model sets out to consider the communication agents in order to understand the logics of news production on immigration. For that purpose, it involves selecting a sample that includes not only journalists but also institutional sources and other agents that influence media discourse in a defined geographical setting. On that basis, it chiefly studies the positions and roles of the communication agents and the communication strategies they use to influence the news, whether as direct producers of news stories or as sources. Additionally, it focuses specifically on studying the interactions amongst the communication agents, based on the consideration that the degree of quality and fluidity of these interactions has a very significant impact on the news stories produced by the mass media.

Based on the study of the roles of the agents and the communication strategies they employ, it establishes valid and common general categories for analysing the

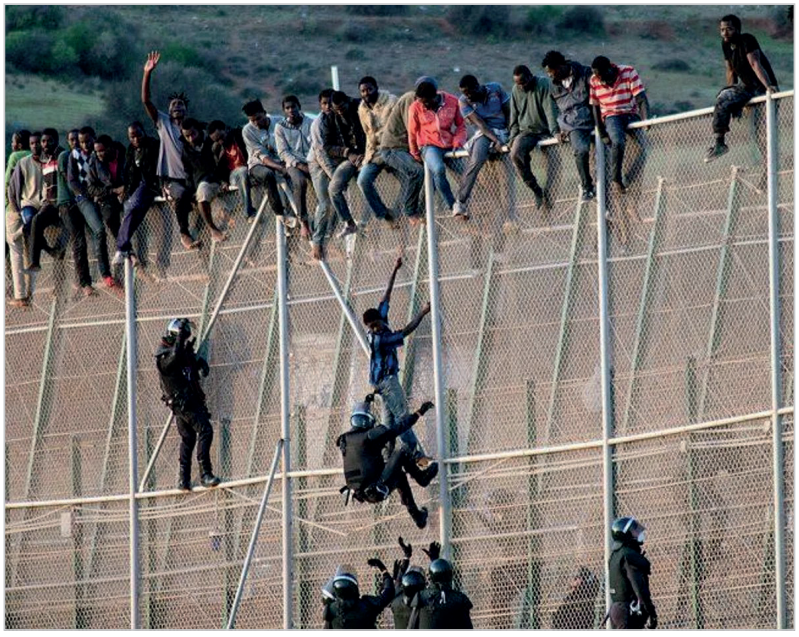

Figure 1. Emigrants trying to enter in Melilla https://www.moroccoworldnews.com/2019/07/278681/hundreds-ofmigrants-rush-border-fence-in-melilla interviews that were conducted with them (journalists, politicians, activists, civil servants, etc.), and other specific categories that make it possible to enquire more deeply into issues that only concern some of the professionals contacted.

Therefore, in the first place, the geographical area to be studied study was restricted in order to obtain significant results and also to take into account the available resources -there was one researcher working on the ground. We selected Melilla for two reasons:

- First, because it is a relevant area in the frontier continuum of southern Europe, both because of the investment aimed at preventing immigration and because of the crossings effected by immigrants in recent decades.

- Second, because the fence at Melilla has acquired great symbolic significance; it has been portrayed and is recognised by audiences internationally, while, in comparative terms, the fence at Ceuta has had much less impact. Furthermore, the fence demarcates the European Union's most economically unequal frontier. The per capita GDP of Spain is fifteen times greater than that of Morocco.

In order to achieve the objective of the research, we contacted all the journalists who regularly cover immigration issues in Melilla. Furthermore, we took into account the role of other informative agents, both institutional (the Government Delegation and the State Security Forces and Corps, the Centre for Temporary Residence of Immigrants) and non-institutional (activists). At the same time, having heard complaints from professionals about obstacles placed on their reporting, it was considered important to interview the Press Association of Melilla. The field work included compiling documents beforehand, exploring the terrain, taking notes and holding informal conversations with people in both Morocco and Melilla. All of this served to contextualise and refine the questionnaires for use in the semi-structured interviews that were conducted with a total of 16 people between 18 and 30 June 2018 . Some interviewees were contacted in advance and others directly in Melilla, according to the needs arising from the development of the fieldwork and the information obtained in the process.

We contacted all the journalists who regularly cover immigration issues in Melilla and took into account the role of other informative agents, both institutional and non-institutional (activists)

To analyse the roles of the communication agents and the strategies they employ to report on immigration on the frontier, certain questions were designed that formed part of the interviews. However, the exploratory character of the study required flexibility and adaptability when talking with the interviewees, and many of the questions put to them were improvised. The following is the skeleton outline of the interview:

Q1: What has to happen for a frontier crossing by immigrants to become news?

Q2: What is the usual procedure followed in collecting/providing news on the arrival of immigrants crossing the fence or by sea?

Q3: What formal and informal work protocols are followed to work inside the frontier perimeter? Do you encounter difficulties in carrying out your work?

Q4: What social function do you believe you are performing when covering news stories about immigration from the frontier?

Q5: As a journalist, what relation do you have with the mass media you work for when covering immigration issues? 
Q6: As a journalist, how do you relate to the local, national and international mass media?

Q7: What is your relationship with other agents present on the frontier and how do they evaluate the way you do your work?

Q8: What are the logics of the information issued by the institutions (State Security Forces and Corps, Government Delegation, Centre for Temporary Residence of Immigrants)?

It is important to point out that this study has an exploratory and inductive character given that the categories were constructed on the basis of the information obtained in the interviews. The following table sets out the categories.

Table 1. Categories

\begin{tabular}{|c|c|c|}
\hline $\begin{array}{l}\text { Structure } \\
\text { of analysis }\end{array}$ & General categories & Specific categories \\
\hline \multirow[t]{3}{*}{ Roles } & Social function & $\begin{array}{l}\text { Introduction. Brief introduction that the interviewee makes of him/herself and } \\
\text { his/her professional experience. } \\
\text { Audiences. The public and mass media for which they work (in the case of the } \\
\text { institutions, the recipients of their press releases). } \\
\text { Editorial line. Definition of the role that the interviewee fulfils and the general } \\
\text { view he or she has of the migratory phenomena and the Law on Foreigners. }\end{array}$ \\
\hline & $\begin{array}{l}\text { Evaluation of the roles assumed by other } \\
\text { agents }\end{array}$ & $\begin{array}{l}\text { Definition of roles. Description of the role that other informative agents play } \\
\text { on the frontier }\end{array}$ \\
\hline & $\begin{array}{l}\text { Evaluation of the media coverage (of the news } \\
\text { stories) }\end{array}$ & $\begin{array}{l}\text { General evaluation of coverage. The evaluation the interviewees make of the } \\
\text { way issues related to immigration are covered. }\end{array}$ \\
\hline \multirow[t]{2}{*}{ Strategies } & Working strategies on the ground & $\begin{array}{l}\text { Promoter of information. Motives that lead the different agents to act as infor- } \\
\text { mants about what is happening on the frontier. } \\
\text { Development of work on the ground. Description of the development of wor- } \\
\text { king on the frontier. Opportunities and difficulties encountered in carrying out } \\
\text { their work. Description of the relations amongst the agents present there. }\end{array}$ \\
\hline & $\begin{array}{l}\text { Strategies for dialoguing with other communi- } \\
\text { cation agents in the course of generating news }\end{array}$ & $\begin{array}{l}\text { Institutional information. Protocols in the emission of news by the institutions. } \\
\text { Interactions amongst the different communication agents. Relations between } \\
\text { the journalists and other direct informants and their sources. }\end{array}$ \\
\hline
\end{tabular}

The people interviewed were:

- The president of the Press Association of Melilla.

- Editors and content managers of the main local mass media in Melilla. In this respect, nearly the entire local media market was covered, including press, radio and television (the newspapers Melilla hoy and El faro; the radio stations Onda Cero, COPE and Popular televisión).

- Three locally based freelance journalists (collaborators of La sexta, El país, El mundo, Tele5, Antena3 and international agencies, amongst other media).

- Regular correspondents of EFE and Europa Press, the two agencies that operate in Melilla.

- The director of the delegation of RTVE in Melilla.

- The director of the Centre for Temporary Residence of Immigrants (Centro de Estancia Temporal de Inmigrantes - CETI).

- The director of the press office of the Government Delegation.

- Members of the Civil Guard associations AUGC and APROGC.

- Trade union delegate of the Unified Police Union (SUP).

- Activists working in favour of human rights.

\section{Results}

The following is a synthesis of the results that could be described as a skeleton outline of the research work. In the first place, we present those results that analyse agents who operate on the frontier as informants and the media that they work for. In the second place, we provide the special features found concerning the working conditions of journalists and other informants on the ground. Finally, we describe the results on the role of the institutions in providing information.

\subsection{Professionals who operate in the frontier area and the media they are attached to}

\subsubsection{A large number of media, little editorial diversity}

After analysing the mass media that work in Melilla on a regular basis, we found that they depend economically on institutional advertising from the city authorities and that their staffs work in very insecure conditions. Furthermore, we observed that these mass media greatly influence media coverage of immigration as they act as producers for the national mass media when this is required by the latter.

With respect to the first point, the mass media market in Melilla is remarkable in qualitative terms and apparently diverse, as a great number of media coexist in a territory of a mere 12 square kilometres that has about 86,000 inhabitants. We found that there are two newspapers of record, three radio and two television stations in the city, as well as the 
delegation of Radio Televisión Española. However, all of them operate with very few staff and the bulk of their financing comes from institutional advertising paid for by the city council. While there is no transparent official information on this question, which would make it possible to learn the amount each medium receives, the absence of media independence is a well-known fact in the journalistic milieu. This was confirmed in the interviews with the people in charge of the main newspapers, radio and television stations, who admit that they depend on these revenues for their survival (in the case of the press, for example, institutional advertising can account for as much as $70 \%$ of total revenues).

In the second place, these media operate with staffs working in insecure conditions, the majority of them young journalists who are overburdened by the volume of local news production and its diffusion through press conferences. There is no competitiveness when it comes to obtaining exclusive news, instead there is an atmosphere of collaboration:

"The fact is that one advantage we have here is that there's a lot of fraternal feeling amongst the media. Since it's such a small place, in addition to being professional colleagues, there's a relationship outside work, you know nearly everyone..." (Director of the RTVE Delegation in Melilla).

For example, the former president of the Press Association of Melilla created a Whatsapp group that includes the majority of the journalists who work regularly on the ground, as well as the former press officer of the Government Delegation. By means of this Whatsapp group the Government Delegation used to inform journalists about different affairs:

"It was created by the Press Association partly to help us, and it ended up being used for saying: listen, wait five minutes, I'm just parking and I'll be a little late for the press conference; as well as for requesting information if immigrants had scaled the fence..." (Journalist from Melilla hoy and director of the EFE agency).

In line with the above, it is worth underlining the predominance of very conservative editorial lines that tend to favour political parties situated on the right of the political spectrum, which have traditionally formed the city government. This is confirmed by the editor of the newspaper El faro.

"The media in Melilla tend to be conservative. What happens is that those of us who come from outside try to provide a more progressive touch (...). I imagine you've been past the Port and seen the statue of Franco, which would be unthinkable in other cities on the Peninsula..." (Editor of El faro).

At the same time -and all the local media content managers that we interviewed agreed on this- the job insecurity affecting all the journalists and the great profusion of institutional information make it very difficult for them to follow current news in Melilla. The numerous press conferences are normally at the centre of their everyday work and it is therefore difficult for them to deal with unexpected occurrences or dedicate the necessary attention to other affairs that go beyond local journalism. In that sense, they identify differences between their role and that of freelance journalists, since the latter can dedicate more time to investigating an issue or giving in-depth coverage to immigration:

“Me and my colleagues... we can't do that. We've done good reportages but focusing on a single individual, who tells you their story. What's reported by a national medium can't be the same as what a local medium reports (...) The person who goes to the CETI has probably just been covering a press conference on something totally unrelated" (Editor of El faro).

It is interesting to see how it is often the local media that act as producers for national mass media when events occur that are considered spectacular. Sometimes they do this for free. Others receive some type of compensation, as can be seen in this extract from an interview:

"We also perform the role of producer and those images are sold to Antena3, or to Tele5... the national media that want to buy them from us" (Editor at Popular TV).

In any case, this is a remarkable role, and it gives some idea of the influence of the local media in Melilla when it comes to transmitting images and discourses that have a national projection.

Finally, we found two news agencies that regularly work in the city: EFE and Europa Press. The same journalists who work for the local mass media also work for these agencies. In fact, two of them work for the newspaper with the largest print run in the city, Melilla hoy.

\subsubsection{Other informants: the activist, the autonomous journalist and the sporadic correspondent}

One especially relevant idea in the information we collected should be emphasised. In general, it has been activists who have provided content on certain illegal practices committed on the frontier that reporters did not reproduce, or else reproduced without in most cases providing any critical perspective or enough follow-up for these practices to enter public discussion. Another notable result is that correspondents prove to be essential for the practice of a more independent journalism in Melilla, although in
The mass media and journalists have ceased to be the only communication agents of interest to researchers 
numerical terms their presence is very limited. This is because it is only when sub-Saharan immigrants scale the fence in large numbers that there is a major presence of journalists from the Peninsula, foreign journalists and international media.

At present, two people can be found who work continuously as autonomous journalists for press and television, and whose stories show very considerable and critical knowledge of the logics in force at the frontier, as well as the need to revitalise the journalistic profession:

"The point is that things have changed a lot from years ago and nothing is the same as before. Nowadays, I believe that you will find the same front pages everywhere, the same photographs, but that's because a lot of work is being done with agencies. I continue to work for myself not for agencies, although at times they ask me to... but normally it's not like that" (Freelance journalist).

Finally, there is the figure of the activist working in favour of human rights who has played a fundamental role in the coverage of immigrants entering Spanish territory. The majority of activists were present in Melilla during the periods when immigrants crossed the fence on the frontier perimeter the greatest number of times (the years 2005 and 2014 2015). Others work in NGOs with specific projects and, finally, there are the very few activists who live in the city permanently. All the journalists interviewed coincided in telling us that their role is different from that of the activists, as they consider that the latter try to achieve concrete goals with their work, while the journalists claim that their role is to report what is happening. One of them explained this as follows:

"It's true that we don't perhaps give as much importance to that image as they do. We say: the Civil Guard has handed the first three immigrants to come down off the fence over to the Moroccan authorities. And we leave it at that. But, of course, they move it on their circuit, giving greater importance to certain aspects" (Editor at Onda cero).

In that sense, we found that the role of activists as generators of information has been primordial when it comes to starting a public debate on issues like the "immediate return of immigrants". The activist and author of the prize-winning photograph in which some immigrants can be seen perched on the fence at Melilla with a view of the city golf course in the background describes his work as follows:

"Well, first you have to collect a news item intentionally, in the sense that you want to demonstrate something that is happening, and no one has the courage to do so, because I often did that, I would be hidden at a certain distance filming, and I could see others who even had permits to be filming and they were down below and the Civil Guard didn't say anything to them. They were filming the same scene as me...but they filmed it and then didn't publish it... (...) So they would always wait, a lot of them would wait, the majority, nearly everyone, for me to put out an image of an immigrant being handed back, and when I brought it out, they wouldn't even publish their own image, but mine instead" (Activist in favour of the rights of immigrants).

Finally, an emerging phenomenon is that ordinary citizens often record the arrival of small boats on their mobile devices, and are the first to send out a warning using the latter. In this respect, information is no longer exclusively in the hands of journalists, and it has become much more difficult to control the ways in which it is obtained and diffused.

\subsection{Prevalence of the image and difficulties of working on the ground: lack of protocols and arbitrariness beyond the criteria of security}

It emerges from the interviews we conducted that Melilla is a hostile environment for practicing journalism. The situation appears to be further aggravated when covering migrations, as factors come into play that exceed the logics of local politics. In this sense, we found that images have been the most important element in the work developed by journalists on the ground. Obtaining an image of the arrival of immigrants at the fence or in a boat and the actions of the security forces continues to be at the centre of journalistic work on the ground.

In that respect, one of the most striking results is that there was and continues to be arbitrariness on the part of the authorities that prevents journalists working at the frontier from accessing information.

Several journalists described situations that indicate a lack of freedom when it comes to reporting, threats received when reporting on cases of corruption in Melilla, colleagues dismissed from jobs in mass media that belong to entrepreneurs with local interests, and a revolving door between institutional press offices and the mass media that points to a significant overlap between the political interests of the city government and a large part of the mass media. Many journalists always work with the assistance of lawyers. Furthermore, the fact that the number of inhabitants is so small is of no help when it comes to reporting, as everyone is obliged to coexist in a reduced space. The following is the explanation given by a critical journalist who for a long time worked on uncovering cases of corruption and who reported that he had received threats and even experienced situations of physical violence for doing his job.

"The problem is that we are bound hand and foot and there is often a wish to avoid problems... I mean, why should I involve myself in the tricky situation of looking into a case of corruption if they are only paying me a 
miserable 950 euros at a newspaper and I am working 14 hours?" (Independent journalist).

To work in the area of the fence, a journalist must request a permit from the Government Delegation, which might take between one and two weeks to arrive and might include a guided visit by the Civil Guard. The other alternative is to film directly, an option that was and is subject to the decisions of the security forces on the frontier. When immigrants scale the fence, a security perimeter is usually set in place that depends on criteria about which journalists are ignorant and that do not always respond to security reasons:

"So, the protocol for activity is what we journalists are always asking for: what is the protocol? They don't specify, so it changes, it varies... depending on the numbers involved, depending on the crossing, depending on those of us who are there, it changes... So of course, that's why we complain. Suddenly they increase the security perimeter, why? (...). As there is no [protocol] they are at the orders of their superiors. When something happens those superiors say: no, he is the one who took that measure. So we can say that there is no mutual support within the security corps. Nor does such support exist..." (Freelance journalist).

In general, the journalists complain about censorship. Some believe that the period of official obscurantism, which they place between the periods when qualitatively striking fence crossings took place (the years 2005 and 2014-15), has ended, while others consider that the restrictions on the right to information continue to be in force, although they are perhaps less evident because there are fewer crossings and less media presence. Nonetheless, the journalists' trade unions and other organisations continue to denounce the news blackout on the southern frontier. In the case of Melilla concretely, this is how several journalists explain the correlation between a major media presence and the limitations on the right to inform:

"At first there are always more possibilities, but as NGOs start to arrive with their cameras and so on, more regulations get ignored or the perimeter becomes very restricted and they try to prevent us from seeing everything that happens. That's the way it is and, in fact, I once received news that they were going to scale the fence before the Civil Guard did, and I was questioned about why I had received that news before them (...). It's a sensation of fear and, besides, in that concrete situation there is a lot of tension, not only because of what is happening but because they are also very alert to the fact that we are watching everything that goes on, so that mutual tension sometimes collides" (Freelance journalist).

"That depends a great deal on what the Government's position is. For example, during the first crisis at the fence, the journalists found themselves in an almost clandestine situation. We weren't allowed there. Then... well... they started to establish a kind of perimeter" (Journalist at Melilla hoy and EFE).

"I remember that period (2013) as very hectic, the fence was scaled every week and the area was cordoned off and you couldn't reach the fence. You could go up onto the hill and use a zoom and watch from afar... and, in fact, the Civil Guard went after the journalists who tried to record that type of news, they asked us for our credentials... and I had to make a statement in the Civil Guard station because I was covering a crossing, they asked for my images and called me to the station. I mean, there was a lot of persecution because I believe they were afraid that we would report what could be seen at the fence related to the immediate return of immigrants and so on" (Editor at Popular TV).

Furthermore, other journalists and activists complain about other tactics that limit the work of reporting by means of penalties, fines and the erasure of images in newsrooms, as can be seen in the following extracts:

"I've already been fined several times. But I've not been fined for taking photos. I've been fined for disobeying a civil guard. You've disobeyed a civil guard, an authority, right? And you say, they told me to leave, and you say, I can't, I don't want to, I can't leave; as a journalist I have to be here because this is happening and I want to cover it. And then they said: very well then, contempt of authority and a fine. It makes you think twice the next time... because the penalty is an economic one and the next time you ask yourself whether it's worth going or not" (Freelance journalist).

“Up to now you often have to go and film at the frontier and you don't have the permits at that moment, they take a couple of hours to arrive, so obviously you don't have time because you have to get there early and you often have to make do as best you can... (...) perhaps going to places where you can film from outside, which is allowed... 
I mean, whatever the lengths you go to in order to film, they will always create obstacles" (Editor RTVE Melilla).

"Well, on the border of course. On the border of course. They took me to the jail, they confiscated my equipment, one piece for a year and a half... the Civil Guard. It was brand new, when they gave it back it was already obsolete (laughs)" (Activist in favour of the human rights of immigrants).

"If you are a journalist you are dangerous at the fence. That's what was happening. (...) At Cablemel I saw it firsthand. A colleague arrived with some really shocking images of the fence in which an immigrant falls to the ground and is doing practically nothing... I didn't even see him do anything violent; they started to give him a brutal thrashing on the ground using sticks, amazing. Those images were never seen and were erased" (Investigative journalist).

In spite of these statements, the majority of the journalists who work in the city's local media have a positive view of the work done by the Civil Guard. Many of them have relatives who work in this security corps and they underline the difficulties faced by the agents when doing their job. Besides, from their statements it can be inferred that they assume there is a level playing field in what they consider to be confrontations between immigrants and the Civil Guard (some people trying to enter and other people trying to prevent this). The following argument was provided by the Unified Association of Civil Guards (AUGC), which represents the majority in the corps, when asked about the restrictions on the right to information:

"In the year 2005-2006 when there were massive fence crossings and so on, I do believe that there were perhaps places... because the journalists often got there first... We didn't hear about the fence crossing sometimes, and the journalists were already there, OK? We were bordering on... journalism was bordering on... because they had direct communication about a crossing, about an invasion, about a massive entrance of immigrants, OK? So things were like that, but information wasn't being denied to them. On the contrary, these were issues involving security and information because we believed... let's see, if we're there with thermal imaging cameras, watching the perimeter, and we don't know that they're coming and that there's going to be a crossing, how is it that the journalist is already in place to photograph the crossing? He had information" (Spokesperson of the AUGC).

When covering arrivals in small boats, the journalists say that they encounter difficulties in reporting when Maritime Rescue brings the immigrants into the port, because the Port Authority is a private entity and journalists have to request permission to enter.

With respect to the role of the Melilla Press Association, there have been no activities aimed at mediating in this type of situations, except for informal conversations with the Civil Guard, according to its current president.

Finally, during the field work information was gathered on two additional difficulties faced by journalists when working that require further investigation:

- The first is the difficulty in monitoring events at the frontier in terms of legality and human rights, since journalists occasionally act as watchdogs and the institutional press offices have no protocols for providing systematic news.

- The second difficulty lies in the insecure working conditions encountered by the few journalists who go to Morocco to cover what is happening there with a broader perspective and fear for their safety.

\section{Discussion and conclusions}

While the greater part of the research carried out to date has focused on studying content to explain the nature of journalistic treatment of immigration, in this work we show that one highly relevant and often overlooked aspect is the importance of the factors that condition news production and the multiple agents who contribute to disseminating content and who therefore affect journalistic news stories.

In that respect, the first conclusion is that journalists are working in an exceptional and insecure way on the frontier between Melilla and Morocco. They complain of censorship and difficulties in gaining access to information when working to cover the arrival of immigrants, including: restrictions on access to the frontier perimeter that go beyond security requirements; being detained or even arrested; seizure of material, fines, etc. According to the field work there have been periods of greater and lesser informational transparency on the part of the authorities, the systematic analysis of which does not fall within the object of this study. However, what is very clear is that the primacy of the criterion of spectacularity in media coverage of the arrival of immigrants, which has so often been noted in studies based on Critical Discourse Analysis or framing, does not depend exclusively on the will of the journalists but on other factors that condition news production. Amongst these we note: 
- the dependence on institutional advertising of the mass media based in Melilla;

- the job insecurity experienced by communications professionals;

- the arbitrariness of the institutions and state security forces when it comes to being more or less permissive in allowing access to information.

In the second place, one frequently overlooked aspect of considerable relevance is the importance of the different professional figures involved in publishing and broadcasting news on this issue. In that sense, working directly on the border (and leaving the institutional sources aside) we found three main figures:

- the freelance journalist,

- the journalist affiliated to a specific medium, and

- the activist.

We conclude that the figures of the freelance journalist and the activist have played a key role in providing news stories of greater depth and in denouncing situations of flagrant human rights violations on the border. This enabled us to study their roles more deeply and confirm that there is an open debate regarding the limits of journalism, as we found that some of the news stories and public debates that have acquired international prominence were put on the agenda by activists rather than by journalists. In that sense, we found that the interviewees clearly differentiate between their roles. The journalist "who recounts what is happening" has a more passive and distant attitude towards events, while the activist who wants "to demonstrate something" has a more active attitude. We believe that this issue provides a new line of research.

In the third place, we observe that the study of news production on the border enables a better understanding of the subsequent itinerary followed by news stories. In this respect, we observe that the limits between the generation of local, national and international news are becoming blurred. This is not only because of the presence of Internet but is also due to the particularities that characterise the work of journalists and the mass media market in the frontier environment, where multiple situations can be found:

- Local mass media that provide information to national mass media;

- Local mass media with many followers at the international level via social media;

- Local journalists who provide information to national media although they are not on their staff;

- Correspondents from other countries who interact with local journalists to obtain information;

- Journalists who work for local mass media (part of their staff) and as delegates of news agencies;

- Local activists with access to international information networks, etc.

This variety does not necessarily lead to greater diversity in the news stories that are published and broadcast. If one looks closely at the media market, one can observe a predominant uniformity in news stories whose control is in a few hands, while there is a great influence of the local mass media, which act as producers for national and even international media.

These three conclusions enable us to return to the theory employed in this work and confirm that journalists wish to maintain the role that they have traditionally been assigned: recounting what happens. Nonetheless, the frame of what is happening is predetermined by the conditions in which journalists work and the information they are allowed to access. While the theory of framing studies the analytical frames provided by texts, the study of news production allows us to begin to understand the opportunity for constructing a frame that is available to the journalist. In the case that concerns us, the study of the arrival of immigrants, we can see that this opportunity is limited by different factors, some of which are indicated in this work. These factors should be analysed in greater depth to better understand the issues that are included in and fall outside the media agenda and what sources or motives intervene in the latter's construction.

This research has future implications for the field of research in the discourses on migrations, as it points to certain questions that could be kept in mind in future works focusing on the content analysis of news products. In that respect, we indicate the importance of specifically studying the content provided by other informants who appear as sources in the news stories, in order to place this content in relation with the roles they supposedly play. Similarly, there is a need to investigate in greater depth what is included in and what falls outside the media agenda, taking into account the greater or lesser transparency of government and institutional sources in providing information and allowing access to data. In that respect, we put forward the hypothesis that there is a relationship between the degree of official permissibility in accessing information and international negotiations on the issue of controlling immigration.
We note the hypothesis of the existence of a relationship between greater or lesser permissibility in access to information and international negotiations on immigration control 


\section{References}

Agirre, Antxoka; Ruiz-Aranguren, María; Cantalapiedra, María-José (2015). "La visibilidad de los centros de internamiento de extranjeros: dinámicas entre el movimiento asociativo y los periodistas". Revista latina de comunicación social, v. 70, n. 8, pp. 913-933.

https://doi.org/10.4185/RLCS-2015-1078en

Alcaraz-Mármol, Gema; Soto-Almela, Jorge (2016). “The semantic prosody of the words 'inmigración' and 'inmigrante' in the Spanish written media: A corpus-based study of two national newspapers". Revista Signos, v. 49, n. 91, pp. $145-67$. https://doi.org/10.4067/S0718-09342016000200001

Allen, William; Blinder, Scott (2013). Migration in the news: Portrayals of immigrants, migrants, asylum seekers and refugees in national British newspapers, 2010-2012. University of Oxford.

https://www.compas.ox.ac.uk/2013/pr-2013-migration_media

Archetti, Cristina (2015). "Terrorism, communication and new media: Explaining radicalization in the digital age". Perspectives on terrorism, v. 9, n. 1, pp. 9-59.

http://www.terrorismanalysts.com/pt/index.php/pot/article/view/401

Armentia-Vizuete, José-Ignacio; Marín-Murillo, Flora; Caminos-Marcet, José-María (2015). "Los homicidios en la prensa vasca (2002-2012): tratamiento informativo y códigos deontológicos". Estudios sobre el mensaje periodístico, v. 21, n. 1, pp. 53-72.

https://doi.org/10.5209/rev_ESMP.2015.v21.n1.49080

Bañón-Hernández, Antonio-Miguel (2002). Discurso e inmigración: propuestas para el análisis de un debate social. Universidad de Murcia. ISBN: $848371289 X$

Barbero-González, Iker (2011). "El tratamiento jurídico de las migraciones internacionales a través de las regulaciones globalistas de gestión de mano de obra". Oñati socio-legal series, v. 1, n. 3, pp. 1-19.

http://opo.iisj.net/index.php/os/s/article/view/8

Bleich, Erik; Bloemraad, Irene; De-Graauw, Els (2015). “Migrants, minorities and the media: Information, representations and participation in the public sphere". Journal of ethnic and migration studies, v. 41, n. 6, pp. 857-73.

https://doi.org/10.1080/1369183X.2014.1002197

Carlson, Matt; Lewis, Seth C. (2015). Boundaries of journalism. Professionalism, practices and participation. Taylor and Francis Inc. ISBN: 9781315727684

https://doi.org/10.4324/9781315727684

Caviedes, Alexander (2015). “An emerging 'European' news portrayal of immigration?". Journal of ethnic and migration studies, v. 41, n. 6, pp. 897-917.

https://doi.org/10.1080/1369183X.2014.1002199

Contreras-Hernández, Paola (2016). “Migración hacia la Unión Europea y España. Debates, análisis y reflexiones en clave de los derechos humanos". Revista de estudios cotidianos, v. 4, n. 1, pp. 62-91.

https://dialnet.unirioja.es/servlet/articulo?codigo $=5568035$

Dell'Orto, Giovanna; Birchfield, Vicki L. (2014). Reporting at the Southern borders. Journalism and public debates on immigration in the U.S. and the E.U. New York and London, Routledge. ISBN: 9780415835886

Fajardo-Fernández, Rocío; Soriano-Miras, Rosa M. (2016). “La construcción mediática de la migración en el Mediterráneo: ¿No-ciudadanía en la prensa española?”. Revista internacional de estudios migratorios, v. 6, n. 1, pp. $141-169$. https://dialnet.unirioja.es/servlet/articulo?codigo $=6564388$

Ferrer-Gallardo, Xavier; Gabrielli, Lorenzo (eds.) (2018). Estados de excepción en la excepción del Estado: Ceuta y MeliIla. Icaria. ISBN: 9788498888287

Fuentes-Osorio, Juan L. (2005). "Los medios de comunicación y el derecho penal”. Revista electrónica de ciencia penal y criminología, v. 7, n. 16.

https://dialnet.unirioja.es/servlet/articulo?codigo $=1307288$

Gemi, Eda; Ulasiuk, Iryna; Triandafyllidou, Anna (2013). “Migrants and media newsmaking practices”. Journalism practice, v. 7, n. 3, pp. 226-281.

https://doi.org/10.1080/17512786.2012.740248

González-Cortés, María-Eugenia; Sierra-Caballero, Francisco; Benítez-Eyzaguirre, Lucía (2014). "Discurso informativo y migración. Análisis de las rutinas productivas de televisión y la diversidad sociocultural en Andalucía". Estudios sobre el mensaje periodístico, v. 20, n. 2, pp. 735-71.

https://doi.org/10.5209/rev_ESMP.2014.v20.n2.47031 
González-de-Bustamante, Celeste (2018). "Beyond the wall: Missing voices in news coverage of the U.S.-Mexico borderlands". En: Voices, ICA 2018 - 68th Annual ICA Conference. Praga.

Hoxha, Abit; Hanitzsch, Thomas (2017). "How conflict news comes into being: Reconstructing 'reality' through telling stories". Media, war \& conflict, v. 11, n. 1, pp. 46-64.

https://doi.org/10.1177/1750635217727313

Last, Tamara; Mirto, Giorgia; Ulusoy, Orçun; Urquijo, Ignacio; Harte, Joke; Bami, Nefeli; Pérez-Pérez, Marta; Macías-Delgado, Flor; Tapella, Amélie; Michalaki, Alexandra; Michalitsi, Eirini; Latsoudi, Efi; Tsepeli, Naya; Chatziprokopiou, Marios; Spijkerboer, Thomas (2017). “Deaths at the borders database: Evidence of deceased migrants' bodies found along the southern external borders of the European Union". Journal of ethnic and migration studies, v. 43, n. 5, pp. 693-712.

https://doi.org/10.1080/1369183X.2016.1276825

McCombs, Maxwell; López-Escobar, Esteban; Llamas, Juan-Pablo (2000). "Setting the agenda of attributes in the 1996 Spanish general election". Journal of communication, v. 50, n. 2, pp. 77-92.

https://doi.org/10.1111/j.1460-2466.2000.tb02842.x

Preston, Paschal (2008). Making the news: Journalism and news cultures in Europe. London and New York: Routledge. ISBN: 9780415461894

Prieto-Andrés, Antonio (2017). “Discurso político sobre la Ley de extranjería en la prensa española". El profesional de la información, v. 26, n. 4, pp. 695-704.

https://doi.org/10.3145/epi.2017.jul.13

Ruiz-Aranguren, María (2014). Construcción del discurso mediático sobre inmigración en tiempos de crisis: periodistas, migrantes e instituciones. Tesis doctoral. Universidad del País Vasco-Euskal Herriko Unibertsitatea. Departamento de Periodismo.

Ruiz-Aranguren, María; Cantalapiedra, María-José (2018a). “Immigration in the media sphere: key political actors' strategies". Communication \& society, v. 31, n. 2, pp. 87-102.

http://dadun.unav.edu/handle/10171/55712

Ruiz-Aranguren, María; Cantalapiedra, María-José (2018b). "La imagen negativa de la inmigración en los medios, ¿cuestión de estrategia?”. Estudios sobre el mensaje periodístico, v. 24, n. 1, pp. 361-378.

https://doi.org/10.5209/ESMP.59955

Suárez-Navaz, Liliana (coord.) (2015). “Etnografías y emergencias en el Mediterráneo: agujeros negros de nuestra modernidad". Revista de dialectología y tradiciones populares, v. 70, n. 2, pp. 265-276.

http://dra.revistas.csic.es/index.php/dra/article/view/476/480

Van-Dijk, Teun A. (2016). "Cincuenta años de estudios del discurso". Discurso y sociedad, v. 9, n. 1-2, pp. 15-32.

https://dialnet.unirioja.es/servlet/articulo?codigo=5409933

Wagman, Daniel (2002). “Imágenes sobre la inmigración. Estadística, delito e inmigrantes”. Mugak, n. 19. http://www.pensamientocritico.org/danwag0902.htm

Wahl-Jorgensen, Karin; Hanitzsch, Thomas (2009). The handbook of journalism studies. London and New York, ICA Handbook Series, Routledge.

https://keralamediaacademy.org/wp-content/uploads/2015/02/Handbook-of-Journalism-Studies.pdf

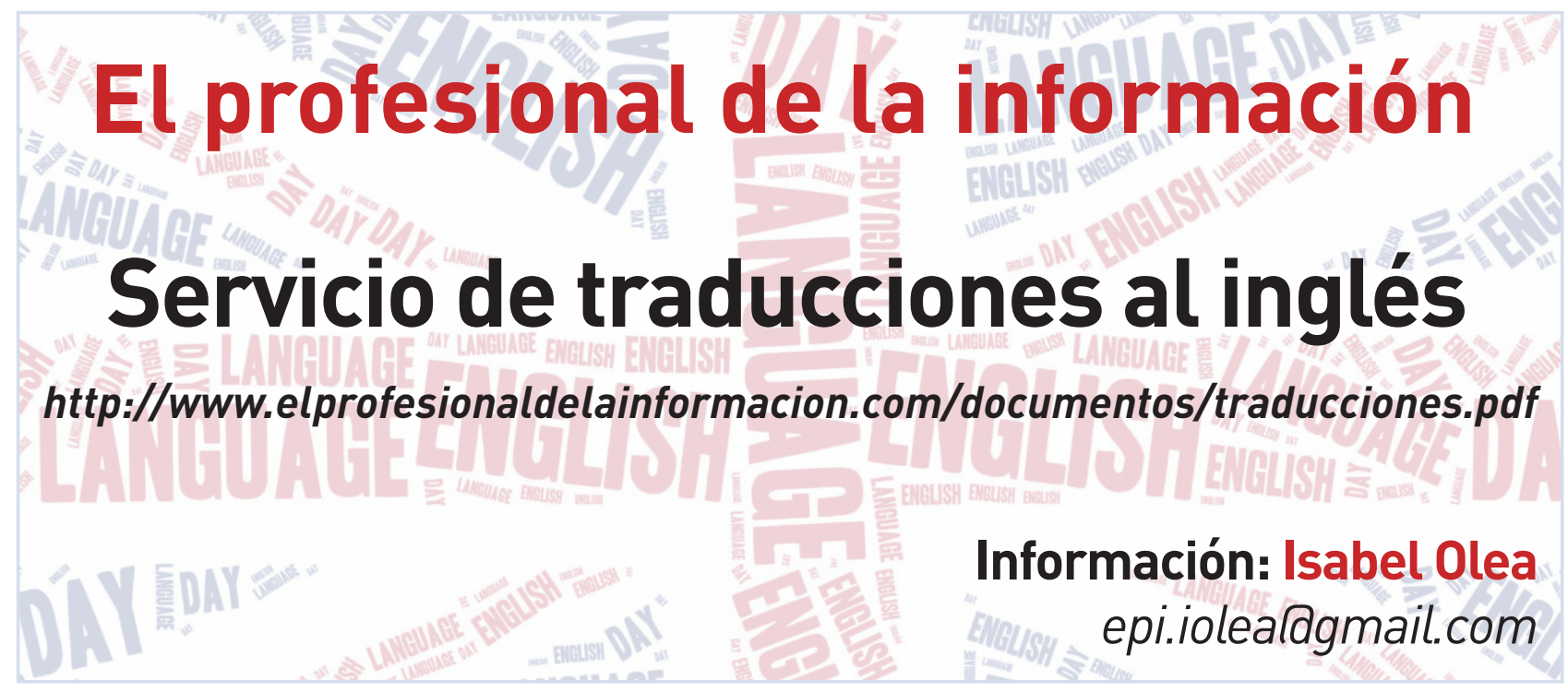

